\title{
Reseñas
}

\section{JOSÉ DEL POZO ARTIGAS “Diccionario histórico de la dictadura cívico-militar en Chile Período 1973-1990 y sus prolongaciones hasta hoy". Santiago, LOM ediciones, 2018.}

Mario Valdés Urrutia, Universidad de Concepción.

Una obra cruda, veraz y digna.

Este libro erudito y editado pulcramente es un diccionario de la dictadura militar con apoyo civil que gobernó Chile entre 1973 y 1990. En otras palabras, podemos afirmar que se trata de una obra de consulta en la cual se recogen, ordenados alfabéticamente, un conjunto de personas que fueron funcionarios del régimen, figuras de la postdictadura, personas ejecutadas durante el periodo, instituciones que actuaron durante esos años; los hechos internacionales que afectaron al país, entre otras situaciones. El texto está centrado en "el sistema opresivo que dominó el país", las acciones realizadas por el régimen cívico militar que dominaron a la sociedad chilena, apuntándose brevemente también las consecuencias que esto acarreó en los aspectos principales elegidos por el autor, esto es: 1. el carácter cívico militar del régimen; 2. Las transgresiones a los Derechos Humanos; 3. Los rasgos del modelo económico; 4. Los caracteres de su proyecto político de democracia protegida; 5 . La cooptación de los sectores sociales subalternos por el régimen; y 6 . Los rasgos que adoptara su reemplazo por parte de un gobierno civil.

Se puede comprender fácilmente que en esta obra, su autor asume un periodo histórico en el cual prosigue el desencuentro político al interior de la sociedad chilena, jalonada por un profundo dolor humano producto principalmente del accionar de la dictadura. Esto predomina inequívocamente en la obra. En verdad, son casi inexistentes los momentos de gratas expectativas y/o esperanzas que fluyen de su lectura para este amplio periodo; es posible que la excepción a esta percepción, la recoja el lector cuando revise la nómina de jueces o abogados que indagaron diversos crímenes que terminaron con sus responsables cumpliendo penas de cárcel, o en el accionar de personas e instituciones que actuaron para proporcionarle un nuevo protagonismo a la democracia chi9lena regresada a su sitial a la democracia en 1990.

José Del Pozo no pretende ser neutral en la elaboración de este diccionario, pero sí riguroso en la aplicación de la metodología que permitió documentar con elementos que permiten arribar a convicciones verdaderas, más allá de dudas razonables, en las diversas entradas contenidas en las secciones temáticas e individuales de su obra. 
Ahora bien, este libro tiene el mérito de identificar ordenadamente la estructura del aparato represivo utilizado en la época de estudio, trazar el mapa de los mecanismos de trasformación económica y sus diversos efectos, protagonistas y beneficiarios; o bien caracterizar claramente algunas unidades de inteligencia política utilizada en la democracia de la post dictadura. Pero el mérito no se agota allí: también ha logrado identificar a diversos colaboradores del régimen cívico militar que perdieron la vida tras denunciar o intentar sacar a la luz diversas irregularidades y crímenes acontecidos al interior de la estructura represiva policial-militar durante el periodo en cuestión. Pero por otra parte, resulta muy meritoria la mirada hacia los protagonistas de la cultura que realizan obras literarias, poéticas, cinematográficas y musicales, entre otras, las cuales contienen un componente crítico - y de resistencia- hacia el dominio del régimen cívico militar. Otro tanto acontece con personas que realizaron obras funcionales al accionar y objetivos del gobierno surgido el once de septiembre de 1973.

Una idea central en los objetivos del autor es que su trabajo sea de utilidad como referencia para quienes estudian el periodo histórico de esta dictadura y el recorrido histórico hasta hoy. En este aspecto su libro constituye un desafío. Un desafío para los estudiosos de la historia, quienes deben hacerse cargo de abordar la historia reciente, especialmente en los espacios subnacionales o locales, donde los acontecimientos históricos no siempre se reprodujeron a escala de lo acontecido en Santiago. Pero además, el estudiosos del Derecho, la Economía, la Antropología, entre otras disciplinas, encontrará en la obra de José del Pozo, diversas sendas que recorrer para profundizar temas y problemas no resueltos históricamente. Permítaseme solamente indicar una cuestión: no existió unanimidad política en las jerarquías militares ni en los mandos de las distintas ramas de las FFAA al momento del golpe de Estado en 1973; tampoco en Carabineros ni en la Policía de Investigaciones; el autor identifica en su diccionario un reducido grupo de oficiales opositores al golpe y al gobierno posterior; pues bien, esta indicación abre además un camino de indagación a través de procesos judiciales, entrevistas posteriores, memorias y relatos de vida, que permiten ir ampliando la base de consulta documental tendiente a detectar otras señas de disidencia y un incremento relativo del número de uniformados que asumieron diversos grados de disidencia, oposición y rechazo al régimen cívico militar o hacia alguno de los aspectos transformadores que dicho gobierno emprendió. Esto abre las posibilidades de indagación de las disidencias militares - policiales en todo el periodo, lo cual podría perfectamente nutrir las investigaciones de tesis universitarias en Derecho, Historia y Economía, al examinar precisamente las disidencias provenientes desde el campo militar en estas áreas. De manera que a partir de este trabajo se pueden enhebrar otras tantas líneas de indagación acerca de la historia reciente del país o de una o varias regiones en particular. 
El trabajo del autor está realizado con dignidad, palabra favorita de nuestra Nóbel Gabriela Mistral. Inunda mi mente esa voz, porque Del Pozo trata con respeto las personas sobre las que entrega información en su obra; sin perjuicio de su conducta política, el horror, la violencia y el dolor inferido a otros. El libro no contiene ninguna ironía, invectiva, ni un insulto para los victimarios, lo cual no evita los estigmas ignominiosos y permanentes que el peso de los hechos hace recaer en aquellos que emergen en esta obra como responsables políticos o ejecutores de actos transgresores de la vida, la dignidad humana u otros actos deleznables. Ciertamente, esto tampoco invalida la legítima postura crítica del autor ni la crudeza del texto. Las verdades históricas son, en muchas ocasiones, bocados de amargo sabor de difícil deglución; generan emociones ingratas, pesar en el ánimo y sensaciones encontradas.

Finalmente, este libro hace pensar acerca de los desencuentros al interior de nuestra sociedad, la importancia de cuidar la democracia y la ampliación de la participación; pero también encontramos elementos controversiales que nos hacen reflexionar acerca de que tal vez nuestra sociedad en los años setentas estaba enferma, desde la perspectiva de la salud mental: ¿cómo ha sido posible tanto desencuentro y vesania en aquella época?

En una palabra, estamos en presencia de una obra comprometida con la verdad histórica, con la razón, con la moral. 